\title{
Antimicrobial Resistance and Extended-Spectrum Beta-Lactamase Production in Enterobacteriaceae Isolates from Household Cats (Felis silvestris catus)
}

\author{
Ana Claudia Souza Andrade', Isabela Carvalho dos Santos ${ }^{1}$, Lidiane Nunes Barbosa ${ }^{2}$, \\ Isabel Cristina da Silva Caetano ${ }^{3}$, Melissa Marchi Zaniolo', Bianca Dias Fonseca ${ }^{4}$, \\ Lisiane de Almeida Martins' ${ }^{1} \&$ Daniela Dib Gonçalves'
}

\begin{abstract}
Background: In Brazil, cats in households has recently increased dramatically, likely due to their lower space and care requirements. We need to know the health of these companion animal species, since they have behavioral patterns that make them an important link in the epidemiological chain. Extended spectrum beta-lactamase producer strains (ESBL) are resistant to penicillin, cephalosporin and monobactam, but they are susceptible to clavulanate. The goal of this study is to detect Enterobacteriaceae that produce extended spectrum beta-lactamase (ESBL) and evaluate the bacterial resistance profile in isolated cats (Felis silvestris catus) that live in a city located at west of Parana state, Brazil.

Materials, Methods \& Results: Swabs were aseptically collected from the anal orifice and oral cavity of 49 female domestic cats that were healthy upon clinical and physical examination, a minimum age of one year, weighing up to $3 \mathrm{~kg}$, and had attended a veterinary clinic specializing in cats, in order to, later, perform the isolation and bacterial identification, antimicrobial sensibility phenotypic test and the phenotypic test to detect ESBL producer strains. From the 98 swabs collected it was possible to perform the bacterial isolation in 68 samples; $40.81 \%$ isolated from anal orifice and $28.57 \%$ isolated from oral cavity. From rectal and oral cavities $77.50 \%$ and $71.42 \%$ of the isolated were identified as Escherichia coli respectively, being $2.94 \%$ considered ESBL producer strains. In relation to bacterial resistance the antibiotics that shown more resistance in anal orifice were ampicillin, amoxicillin, nalidixic acid, sulfazotrim, tetracycline and aztreonam. In oral cavity they were ampicillin, amoxicillin, cefoxitin, amoxicillin + clavulanate, aztreonam, ceftriaxone and nalidixic acid; and the bacterial resistance index shown that $39.70 \%$ were considered high level risk.

Discussion: Household cats have a very important role in society, since the benefits they provide to their owners are clear, however, it is worth pointing out that these animals also pose risks to human health, caused by the transmission of zoonoses and also the possibility of transfer of antimicrobial resistance genes between bacteria of animal and human origin, as well as between bacteria of the normal microbiota and pathogenic microorganisms of diferents origins. Therefore, it is important to understand the health of these companion animal species, because they exhibit behavioral patterns that make them an important link in the epidemiological chain of potentially infectious microorganisms, which may show antimicrobial resistance. Extended spectrum beta-lactamase producer strains (ESBL) are resistant to penicillin, cephalosporin and monobactam, but they are susceptible to clavulanate. These enzymes hydrolyze the beta-lactam ring of the antibiotic structure, inactivating them. Nowadays bacterial resistance is considered to be one of the greatest problems in public health worldwide, as infections and diseases outbraks are caused by multiresistant bacteria are more and more frequent. The results of this study demonstrate the presence of strains of Enterobacteriaceae family associated to the high bacterial resistance, with samples that indicate ESBL producer strains in domiciled cats, in a city of west Parana state in Brazil. These results confirm that these cats can be considered as reservoirs of different microbial agents and resistance gens, being a health problem by the possibility of dissemination. The cat population is multiplying in a higher proportion compared to dogs and may probably became predominant in less than one decade. Due this situation and thinking about human, animal and environmental health new phenotypic studies to confirm the resistance gens and ESBL producers should be conducted in this specie.
\end{abstract}

Keywords: Enterobacteriaceae, ESBL, felines, bacterial resistance, micro-organism, health.

DOI: 10.22456/1679-9216.90206

${ }^{1}$ Programa de Pós-graduação, ${ }^{2}$ Bolsista PNPD/CAPES/UNIPAR \& ${ }^{3}$ Bolsista da Fundação Araucária, Programa de Pós-graduação em Ciência Animal com Ênfase em Produtos Bioativos, Universidade Paranaense (UNIPAR), Umuarama, PR, Brazil. ${ }^{4}$ Graduação, Medicina Veterinária, UNIPAR, Umuarama. CORRESPONDENCE: D.D. Gonçalves [danieladib@prof.unipar.br - Tel.: +55 (44) 3621-2828]. Programa de Pós-graduação em Ciência Animal com Ênfase em Produtos Bioativos, Universidade Paranaense (UNIPAR). Praça Mascarenhas de Moraes n. 4282. Bairro Centro. CEP 87502-210 Umuarama, PR, Brazil. 


\section{INTRODUCTION}

The presence of cats in homes has increased, however it is necessary to know about the health of these animals, since they are important links in the epidemiological chain of microorganisms that present bacterial resistance [27]. This is considered one of the biggest public health problems because infections are common. In some cases, the microorganisms are resistant to the available antimicrobial drugs [10,16,25,26,28].

The emergence of the selection of multidrugresistant strains is related to the inappropriate use of antimicrobials, besides their use as growth promotion and prophylaxis, in the case of veterinary medicine. In these cases, the doses of antibiotics used are lower than the therapeutic ones, which facilitate mutations and/or acquisition of resistance genes $[4,11,16,25]$.

Strains of extended-spectrum beta-lactamases (ESBL) are resistant to penicillins, cephalosporins and monobactams, but are sensitive to clavulanate [19]. These enzymes hydrolyze the beta-lactam ring of the antibiotic structure, inactivating them. Currently, more than 370 ESBL variant are known $[13,15,16,19]$. Therefore, the aim of this study was to identify Enterobacteriaceae isolated from household cats (Felis silvestris catus), to evaluate their antibiotic resistance profiles and to detect extended-spectrum beta-lactamases (ESBL) in a city in the western region of the State of Parana, Brazil.

\section{MATERIALS AND METHODS}

\section{Sampling}

The total number of cats that attended a Veterinary Clinic specializing in felines in a city in the western region of Paraná in a 1-year period $(n=840)$ was used as the subject pool for this study. The formula used to determine the minimum number of samples for discrete data was the following [24].

$\mathrm{n} 0=\left(\mathrm{z}^{\wedge} 2 \cdot \mathrm{p} \cdot \mathrm{q}\right) /((\mathrm{P}-\mathrm{p}) 2)$ and $\mathrm{n}=\mathrm{n} 0 /(1+\mathrm{n} 0 / \mathrm{N})$

where $\mathrm{n} 0=$ initial number

$\mathrm{z}=$ level of confidence

$\mathrm{p}=$ value obtained from previous studies by others or when not known, set at $50 \%$

$\mathrm{N}=$ population size

$\mathrm{q}=100-\mathrm{p}$

and $\mathrm{P}-\mathrm{p}=$ accuracy determined by the researcher $(15 \%)$

$\mathrm{n} 0=\left[(1.96)^{\wedge} 2.50 .50\right) /((15) 2]$

$\mathrm{n} 0=42.68$ $\mathrm{n}=42.68 /(1+42,68 / 840) \mathrm{n}$ minimum $=40.6=41$ samples.

Study location and population

Swabs were aseptically collected from the anal orifice and oral cavity of 49 female domestic cats that were healthy upon clinical and physical examination, a minimum age of one year, weighing up to $3 \mathrm{~kg}$, and had attended a veterinary clinic specializing in cats. All swabs were collected moments before the completion of surgical castration, while preserving the resident microbiota and avoiding any contamination from the external environment.

\section{Sample collection}

Samples from the anal orifice and oral cavity were collected using sterile swabs Copan ${ }^{2}$ with Amies medium + activated charcoal. Samples were collected from the oral cavity by introducing the swab into the oral cavity of each cat and moving the swab in a circular and rotatory motion against the gums and tongue. Then, a sample was collected from the anal region by compressing and rotating the swab. All samples were stored under refrigeration and forwarded to the Laboratory of Preventive Veterinary Medicine and Public Health of the Graduate Program in Animal Science with Emphasis in Bioactive Products of the University of Paraná (UNIPAR).

\section{Bacterial isolation}

Swabs containing the anal and oral samples were introduced into tubes containing $3.0 \mathrm{~mL}$ of Brain Heart Infusion (BHI) culture medium and incubated at $37^{\circ} \mathrm{C}$ for $24 \mathrm{~h}$. Then, the cultures were streaked on MacConkey agar plates containing cefotaxime $(10 \mu \mathrm{g} /$ $\mathrm{mL}$ ) and incubated for $24 \mathrm{~h}$ at $37^{\circ} \mathrm{C}$ to isolate colonies resistant to cephalosporins. The isolated colonies were inoculated into BHI medium, and then stored in $10 \%$ glycerol at $-20^{\circ} \mathrm{C}$ until use $[22,23]$.

\section{Biochemical identification of bacterial isolates}

Bacteria belonging to the Enterobacteriaceae family were biochemically identified by using the set of biochemical tests included in the Kit for Enterobacteriaceae ${ }^{2}$, according to the manufacturer's instructions $[22,23]$.

Phenotypic testing for sensitivity to antimicrobial agents

The resistance profile of each isolate was determined by the agar diffusion method, according 
to the guidelines of the Clinical and Laboratory Standards Institute [6]. After incubation, the diameter of the zone of inhibition around each antibiotic disk was measured to determine sensitivity or resistance. The antimicrobials tested were gentamicin (GEN, $10 \mu \mathrm{g}$ ), ciprofloxacin (CIP, $5 \mu \mathrm{g}$ ), sulfazotrim (SUT, $25 \mu \mathrm{g}$ ), ceftazidime (CAZ, $30 \mu \mathrm{g}$ ), amikacin (AMI, $30 \mu \mathrm{g}$ ), aztreonam (ATM, $30 \mu \mathrm{g}$ ), chloramphenicol (CLO, 30 $\mu \mathrm{g}$ ), ampicillin (AMP, $10 \mu \mathrm{g}$ ), tobramycin (TOB, 10 $\mu \mathrm{g})$, cefoxitin $(\mathrm{CFO}, 30 \mu \mathrm{g})$, ceftriaxone (CRO, $30 \mu \mathrm{g})$, cefotaxime (CTX, $30 \mu \mathrm{g}$ ), tetracycline (TET, $30 \mu \mathrm{g}$ ), amoxicillin (AMO, $10 \mu \mathrm{g}$ ), amoxicillin + clavulanate (AMC, $30 \mu \mathrm{g}$ ), imipenem (IMP, $10 \mu \mathrm{g}$ ), meropenem $(\mathrm{MER}, 10 \mu \mathrm{g}$ ) and norfloxacin (NOR, $10 \mu \mathrm{g}$ ). As the samples were isolated from animals, two antimicrobials exclusively for veterinary use, enrofloxacin (ENO, $5 \mu \mathrm{g}$ ) and ceftiofur (CEF, $30 \mu \mathrm{g}$ ), were also included.

\section{Multiple Antimicrobial Resistance Index (IRMA)}

The presence of multidrug resistance was determined using the multiple antibiotic resistance (MAR) index, which is defined as $a / b$, where $a$ is the number of antimicrobials to which the isolate is resistant, and $b$ the number of antimicrobials that were included in the test. A value $>0.200$ suggest a high risk to public health [12].

\section{Phenotypic testing for ESBL production}

To evaluate the isolate for ESBL production, a double disc synergy test was performed. In this test, discs containing cefotaxime (CTX, $30 \mu \mathrm{g}$ ), ceftazidime $(\mathrm{CAZ}, 30 \mu \mathrm{g})$, ceftriaxone (CRO, $30 \mu \mathrm{g})$ and aztreonam (ATM, $30 \mu \mathrm{g}$ ) were distributed at a distance of $20 \mathrm{~mm}$ from a disc containing amoxicillin + clavulanate (20/10 $\mu \mathrm{g})$. Any increase or distortion in the zone of inhibition for one of the antibiotics towards the amoxicillin + clavulanate disk is considered to be suggestive of ESBL production [2].

\section{RESULTS}

After screening with cefotaxime, bacteria were isolated from 68 of the 98 samples collected; 40 were isolated from the anal orifice, and 28 were isolated from the oral cavity. Of the 28 isolates from the oral cavity, $20(71.4 \%)$ were identified as E. coli, two (7.15\%) were Serratia rubidaea, three (10.72\%) were Kluyvera spp., and one (3.57\%) each were Edwardsiella tarda, Hafnia alvei, and Morganella morganii (Table 1). Of the 40 isolates from the anal orifice, 31 (77.50\%) were identified as E. coli and one each $(2.50 \%)$ was identified as S. rubidaea, Erwinia herbicola, Pragia fontium, Enterobacter aerogenes, Proteus vulgaris and M. morganii. Three isolates $(7.50 \%)$ could not be identified (Table 1). E. coli was concomitantly isolated from both the anal orifice and oral cavity in 10 out of $49(14.70 \%)$ study subjects (Table 1$)$.

Table 3 shows the resistance profiles of the Enterobacteriaceae isolates. The six antibiotics to which isolates from the anal orifice showed the greatest resistance were ampicillin, with 19 resistant isolates, followed by amoxicillin with 18 isolates, nalidixic acid, with 11 isolates, sulfazotrim and tetracycline with 10 isolates each, and aztreonam with 9 isolates. For isolates from the oral cavity, resistance to ampicillin was most common, with 22 resistant isolates, followed by amoxicillin, with 18 isolates, cefoxitin with 15 isolates, amoxicillin + clavulanic acid, with 14 isolates, aztreonam with 11 isolates, and finally ceftriaxone and nalidixic acid, with 10 isolates each.

The MAR index revealed that 27 of the 68 $(39.70 \%)$ isolates were considered high risk, including 9 from the anal orifice and 18 from the oral cavity (Table 4).

Regarding ESBL production, two (2.94\%) isolates from the oral cavity that were identified as E. coli presented characteristics indicative of ESBL production, as shown by the distortion in the zones of inhibition in the double disk test (Table 1 and Figure 1).

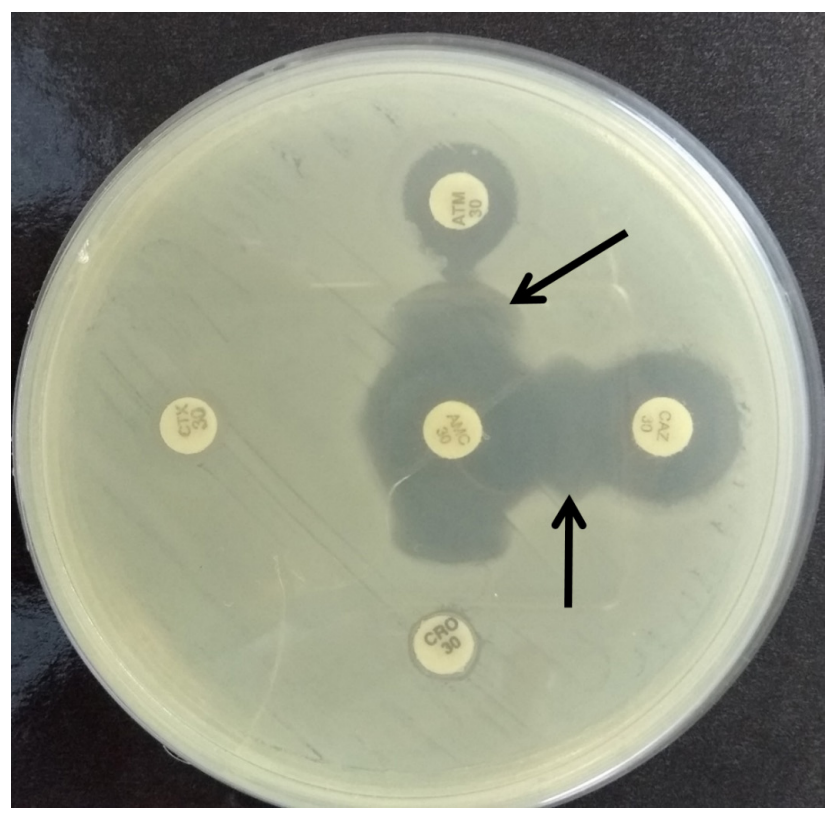

Figure 1. ESBL production by an Escherichia coli isolate from the oral cavity of a household cat (Felis silvestris catus). Distortion in the zone of inhibition, indicated by the arrows, suggests ESBL production. 
Table 1. Profile of the Enterobacteriaceae isolates from swabs of the oral cavity and anal orifice of 49 household cats (Felis silvestris catus) in 2017.

\begin{tabular}{|c|c|c|c|}
\hline \multirow{2}{*}{ Sample } & \multicolumn{2}{|c|}{ Bacterial isolates } & \multirow{2}{*}{ ESBL production } \\
\hline & Anal orifice & Oral cavity & \\
\hline 01 & Escherichia coli & Escherichia coli & \\
\hline 02 & Escherichia coli & Escherichia coli & + \\
\hline 03 & Escherichia coli & Serratia rubidaea & \\
\hline 04 & Serratia rubidaea & Escherichia coli & \\
\hline 05 & Escherichia coli & - & \\
\hline 06 & Escherichia coli & Serratia rubidaea & \\
\hline 07 & - & - & \\
\hline 08 & Erwinia herbicola & Escherichia coli & \\
\hline 09 & Escherichia coli & Escherichia coli & \\
\hline 10 & Escherichia coli & - & \\
\hline 11 & Escherichia coli & Escherichia coli & + \\
\hline 12 & Escherichia coli & - & \\
\hline 13 & - & Escherichia coli & \\
\hline 14 & Escherichia coli & Escherichia coli & \\
\hline 15 & Escherichia coli & Escherichia coli & \\
\hline 16 & Escherichia coli & Escherichia coli & \\
\hline 17 & - & Escherichia coli & \\
\hline 18 & Escherichia coli & - & \\
\hline 19 & Pragia fontium & Escherichia coli & \\
\hline 20 & - & Escherichia coli & \\
\hline 21 & Escherichia coli & Escherichia coli & \\
\hline 22 & - & - & \\
\hline 23 & Escherichia coli & - & \\
\hline 24 & Escherichia coli & - & \\
\hline 25 & Escherichia coli & - & \\
\hline 26 & Enterobacter aerogenes & Escherichia coli & \\
\hline 27 & Not identified* & Kluyvera spp. & \\
\hline 28 & Proteus vulgaris & - & \\
\hline 29 & Escherichia coli & - & \\
\hline 30 & Escherichia coli & - & \\
\hline 31 & Not identified* & Kluyvera spp. & \\
\hline 32 & - & Kluyvera spp. & \\
\hline 33 & Escherichia coli & Edwardsiella tarda & \\
\hline 34 & Escherichia coli & Escherichia coli & \\
\hline 35 & Escherichia coli & - & \\
\hline 36 & Escherichia coli & - & \\
\hline 37 & Escherichia coli & - & \\
\hline 38 & - & Escherichia coli & \\
\hline 39 & Escherichia coli & - & \\
\hline 40 & Not identified* & Escherichia coli & \\
\hline 41 & - & Escherichia coli & \\
\hline 42 & Escherichia coli & Hafnia alvei & \\
\hline 43 & - & - & \\
\hline 44 & Escherichia coli & Escherichia coli & \\
\hline 45 & Escherichia coli & - & \\
\hline 46 & Escherichia coli & - & \\
\hline 47 & Escherichia coli & Morganella morganii & \\
\hline 48 & Morganella morganii & - & \\
\hline 49 & Escherichia coli & - & \\
\hline
\end{tabular}


Table 2. Absolute $(\mathrm{N})$ and relative (\%) frequency of Enterobacteriaceae isolates on swabs of the oral cavity and anal orifice of 49 household cats (Felis silvestris catus).

\begin{tabular}{|c|c|c|c|c|}
\hline \multirow{3}{*}{ Identification } & \multicolumn{4}{|c|}{ Number of isolates } \\
\hline & \multicolumn{2}{|c|}{ Anal orifice } & \multicolumn{2}{|c|}{ Oral cavity } \\
\hline & $\mathrm{n}^{\mathrm{o}}$ & $\%$ & $\mathrm{n}^{\mathrm{o}}$ & $\%$ \\
\hline Escherichia coli & 31 & 63.27 & 20 & 40.82 \\
\hline Serratia rubidaea & 01 & 2.04 & 02 & 4.08 \\
\hline Pragia fontium & 01 & 2.04 & - & - \\
\hline Enterobacter aerogenes & 01 & 2.04 & - & - \\
\hline Kluyvera spp. & - & - & 03 & 6.12 \\
\hline Morganella morganii & 01 & 2.04 & 01 & 2.04 \\
\hline Hafnia alvei & - & - & 01 & 2.04 \\
\hline Edwardsiella tarda & - & - & 01 & 2.04 \\
\hline Proteus vulgaris & 01 & 2.04 & - & - \\
\hline Erwinia herbicola & 01 & 2.04 & - & - \\
\hline Cefotaxime-resistant GNB* & 03 & 6.12 & - & - \\
\hline No bacterial growth** & 09 & 18.37 & 22 & 44.90 \\
\hline TOTAL & 49.00 & 100.00 & 49.00 & 100.00 \\
\hline
\end{tabular}

$\mathrm{N}=$ number of samples; $\%=$ percentage; $\mathrm{GNB}=$ gram-negative bacilli; *Identification within the Enterobacteriaceae family was not possible; **No bacterial growth in the presence of cefotaxime in the first isolation.

Table 3. Resistance profiles of Enterobacteriaceae isolates from swabs of the oral cavity and anal orifice of 49 household cats (Felis silvestris catus).

\begin{tabular}{|c|c|c|c|c|c|c|}
\hline \multirow{3}{*}{ Antibiotic } & \multicolumn{4}{|c|}{ Resistant isolates } & \multicolumn{2}{|c|}{$\begin{array}{c}\text { Anal orifice }+ \text { oral } \\
\text { cavity }\end{array}$} \\
\hline & \multicolumn{2}{|c|}{ Anal orifice } & \multicolumn{2}{|c|}{ Oral cavity } & \multirow[b]{2}{*}{ Total } & \multirow[b]{2}{*}{$\%$} \\
\hline & $\mathrm{R}$ & $\%$ & $\mathrm{R}$ & $\%$ & & \\
\hline Norfloxacin & - & - & - & - & - & - \\
\hline Enrofloxacin & 02 & 5.00 & 01 & 3.57 & 03 & 4.41 \\
\hline Nalidixic Acid & 11 & 27.50 & 10 & 35.71 & 21 & 30.88 \\
\hline Ciprofloxacin & - & - & - & - & - & - \\
\hline Tobramycin & 08 & 20.00 & 02 & 7.14 & 10 & 14.71 \\
\hline Amikacin & 02 & 5.00 & - & - & 02 & 2.94 \\
\hline Gentamicin & 06 & 15.00 & 03 & 10.71 & 09 & 13.24 \\
\hline Meropenem & 02 & 5.00 & 02 & 7.14 & 04 & 5.88 \\
\hline Imipenem & 02 & 5.00 & 02 & 7.14 & 04 & 5.88 \\
\hline Ertapenem & 02 & 5.00 & 03 & 10.71 & 05 & 7.35 \\
\hline Ceftazidime & 04 & 10.00 & 05 & 17.86 & 09 & 13.24 \\
\hline Ceftriaxone & 05 & 12.50 & 10 & 35.71 & 15 & 22.06 \\
\hline Cefotaxime & 08 & 20.00 & 14 & 50.00 & 22 & 32.35 \\
\hline Ceftiofur & - & - & 02 & 7.14 & 02 & 2.94 \\
\hline Cefoxitin & 05 & 12.50 & 15 & 53.57 & 20 & 29.41 \\
\hline Cefepime & 01 & 2.50 & 02 & 7.14 & 03 & 4.41 \\
\hline Ampicillin & 19 & 47.50 & 22 & 78.57 & 41 & 60.29 \\
\hline Amoxicillin & 18 & 45.00 & 18 & 64.29 & 36 & 52.94 \\
\hline Amoxicillin+Clavulanate & 08 & 20.00 & 14 & 50.00 & 22 & 32.35 \\
\hline Aztreonam & 09 & 22.50 & 11 & 39.29 & 20 & 29.41 \\
\hline Sulfazotrim & 10 & 25.00 & 09 & 32.14 & 19 & 27.94 \\
\hline Tetracycline & 10 & 25.00 & 04 & 14.29 & 14 & 20.59 \\
\hline Chloramphenicol & 03 & 7.50 & 09 & 32.14 & 12 & 17.65 \\
\hline
\end{tabular}

$\mathrm{R}=$ Resistant; \%= Percentage. 
A.C.S.Andrade, I.C. Santos, L.N. Barbosa, et al. 2018. Antimicrobial Resistance and Extended-Spectrum Beta-Lactamase Production in Enterobacteriaceae Isolates from Household Cats (Felis silvestris catus). ActaScientiae Veterinariae.47:1630.

Table 4. Multiple antimicrobial resistance Indices (IRMA) of Enterobacteriaceae isolates from swabs of the oral cavity and anal orifice of 49 household cats (Felis silvestris catus).

\begin{tabular}{|c|c|c|}
\hline \multirow{2}{*}{ Sample } & \multicolumn{2}{|c|}{ MAR index } \\
\hline & Anal orifice & Oral cavity/ESBL \\
\hline 01 & 0.087 & 0.000 \\
\hline 02 & 0.348 & $0.304 /+$ \\
\hline 03 & 0.000 & 0.348 \\
\hline 04 & 0.261 & 0.609 \\
\hline 05 & 0.130 & - \\
\hline 06 & 0.217 & 0.217 \\
\hline 07 & - & - \\
\hline 08 & 0.609 & 0.043 \\
\hline 09 & 0.043 & 0.000 \\
\hline 10 & 0.130 & - \\
\hline 11 & 0.435 & $0.522 /+$ \\
\hline 12 & 0.000 & - \\
\hline 13 & - & 0.391 \\
\hline 14 & 0.130 & 0.391 \\
\hline 15 & 0.217 & 0.348 \\
\hline 16 & 0.174 & 0.478 \\
\hline 17 & 0.000 & 0.522 \\
\hline 18 & 0.000 & - \\
\hline 19 & 0.174 & 0.174 \\
\hline 20 & - & 0.130 \\
\hline 21 & 0.000 & 0.217 \\
\hline 22 & - & - \\
\hline 23 & 0.217 & - \\
\hline 24 & 0.130 & 0.130 \\
\hline 25 & 0.174 & - \\
\hline 26 & 0.087 & 0.217 \\
\hline 27 & 0.435 & 0.310 \\
\hline 28 & 0.261 & 0.217 \\
\hline 29 & - & 0.304 \\
\hline 30 & 0.000 & 0.000 \\
\hline 31 & 0.217 & 0.261 \\
\hline 32 & - & 0.000 \\
\hline 33 & 0.000 & 0.435 \\
\hline 34 & 0.000 & 0.000 \\
\hline 35 & 0.000 & - \\
\hline 36 & 0.000 & - \\
\hline 37 & 0.522 & - \\
\hline 38 & - & 0.174 \\
\hline 39 & 0.000 & - \\
\hline 40 & 0.174 & 0.000 \\
\hline 41 & - & 0.217 \\
\hline 42 & 0.000 & 0.174 \\
\hline 43 & - & - \\
\hline 44 & 0.000 & 0.000 \\
\hline 45 & 0.217 & - \\
\hline 46 & 0.174 & - \\
\hline 47 & 0.087 & 0.043 \\
\hline 48 & 0.130 & - \\
\hline 49 & 0.043 & - \\
\hline
\end{tabular}

It were suggested that values $>0.200$ indicate high-risk isolates + , Produced extended spectrum beta-lactamases (ESBL) [12]. 


\section{DISCUSSION}

Companion animals, mainly dogs and cats, play a very important role in society, as they provide various benefits to their owners. However, it is worth noting that despite the multiple benefits that these animals offer, they also pose risks to human health, namely the possible transmission of zoonoses. Such risks are related to the transmission of parasitic and bacterial diseases and even the possibility of antimicrobial resistance gene transfer between bacteria of animal and human origin, as well as between the normal microbiota and potentially pathogenic microorganisms of different origins $[1,8,3,18]$.

It is well known that warm-blooded animals have commensal microbiota in different regions of the body, including the anal orifice and oral cavity. In this study of 98 collected swabs from 49 study subjects, bacteria were isolated from 40/49 (82\%) samples from the anal orifice and 28/49 (57\%) samples from the oral cavity of household cats in the western region of Paraná, Brazil. Of these bacterial isolates, only three were not identified (Table 1). E. coli was the most frequent isolate, comprising $77.50 \%$ of the isolates from the anal orifice and $71.42 \%$ of the isolates from the oral cavity.

The high frequency of E. coli isolates in this study is in agreement with previous results, who isolated 95 (46.34\%) E. coli strains of fecal origin from healthy cats in, São Paulo, Brazil [3] and were isolated seven $(70 \%)$ E. coli strains of urinary origin from cats with urinary tract infections in different regions in São Paulo [5].

These results show that although $E$. coli is a commensal of domestic animals, it is also an important emerging pathogen, since it has sophisticated mechanisms of virulence, which may be responsible for nosocomial and community infections in humans and different animals [3,27].

The observed similarities among $E$. coli clinical isolates from the intestinal and urinary tracts of humans, dogs, and cats implicates these animals in the transmission of intestinal and extra-intestinal pathogenic strains to humans, which is a public health concern [3].

In addition to $E$. coli, other bacterial species, including $S$. rubidaea, Kluyvera spp., E. tarda, H. alvei and M. morganii, E. herbicola, P. fontium, E. aerogenes and $P$. vulgaris, were detected (Table 1). These bacte- ria also belong to the human microbiota $[14,21]$ and somehow seem to have bypassed interspecific barriers and have contaminated the cats in this study. Although this understandable since these animals live in the same household and share the same space as their owners, which favors constant exchange between the human and pet microbiota.

The hygiene habits of cats may facilitate the movement of bacteria in the environment, their feed, and their own feces, thus contaminating their oral cavity with fecal and environmental bacteria.

It is worth noting that in this study, when there was bacterial growth in the BHI medium, the samples were inoculated onto MacConkey agar plates supplemented with cefotaxime $10 \mu \mathrm{g} / \mathrm{mL}$ to detect ESBL, and were then tested against 23 antibiotics. A high percentage of bacterial resistance was found even in the presence of cefotaxime $(10 \mu \mathrm{g} / \mathrm{mL})$. This result probably reflects the increased use of these drugs in clinical practice in the western region of Paraná, as various studies have demonstrated that the continued and irrational use of certain drugs exerts selection pressure on both pathogens and normal microbiota, which can affect the health of humans and animals and have profound consequences in the environment, since this is where complex interactions among microorganisms, resistance genes, and their respective hosts occur $[7,9,20,27]$.

Another important result are the MAR indices, which suggested that $39.70 \%$ (27/68) of the isolates were high risk, including $22.50 \%$ of the isolates from the anal orifice and $64.28 \%$ of the isolates from the oral cavity. This finding of $64.28 \%$ potentially high-risk isolates in the oral cavity of asymptomatic household cats is worrying, especially since these animals use their tongue to bathe and may be disseminating resistance genes to their owners, other animals, and the environment.

Another factor that may be related to the observed high antibiotic resistance is quorum sensing, since it is known that quorum sensing can alter the behavior of bacteria, promoting the production of biofilms, enterotoxins, and the acquisition of resistance genes [17]. Given that the bacteria isolated in this study are from the anal and oral microbiota, a large number of other microorganisms may be affecting the behavior of the isolates evaluated in this study.

Two E. coli isolates showed characteristics indicative of ESBL production, and these isolates were also considered high risk by MAR index. This 
result is concordant with data from in the region of Ituverava, state of São Paulo, who also detected two $(0.88 \%)$ suspected ESBL-producing E. coli isolates from healthy cats [27].

The suspected ESBL-producing strains were isolated from the oral cavity, which reinforces the concerns related to felines, especially because of their hygiene habits and the possibility of resistance gene transmission. It is worth noting that strains which present this phenotype are resistant to all cephalosporins, including third and fourth generation cephalosporins, and may also present concomitant resistance to other groups of antimicrobials, especially quinolones.

\section{CONCLUSIONS}

Our results demonstrate the presence of highly resistant Enterobacteriaceae isolates and suspected ESBL-producing strains in household cats in western Paraná, Brazil. These results confirm that household cats can be considered to be reservoirs of multidrugresistant microorganisms bearing resistance genes that could be a serious public health problem, considering the possibility of spread between cats and humans.

The cat population is multiplying at a much higher rate than the dog population, and cats may be- come the predominant pet in the near future. Because of this, and their potential impact on the health of humans and animals and the environment, additional phenotypic and molecular studies should be conducted in this animal species to confirm the presence of resistance genes and ESBL production. As it is evident that microbes may be shared between the cats and their owners due to the higher detection of microorganisms in the oral cavity, most likely as a result of cats' hygiene habits.

\section{MANUFACTURERS}

${ }^{1}$ COPAN Diagnostics inc. Murrieta, CA, USA.

${ }^{2}$ NewProv Produtos para Laboratórios. Pinhais, PR, Brazil.

Funding. This research was supported by CAPES.

Acknowledgements. The authors would like to thank UNIPAR and the Araucaria Foundation for funding this research, CAPES for scholarships, and the cat owners for their cooperation.

Ethical approval. This study was approved by the Ethics Committee on Animal Experimentation of the University of Umuarama, Paraná (UNIPAR); protocol no. 32461/2017, dated 07/04/2017).

Declaration of interest. The authors report no conflicts of interest. The authors are solely responsible for the content and the writing of this paper.

\section{REFERENCES}

1 Benitez A., Gonçalves D.D., Nino B.S.L., Caldart E.T., Freire R.L. \& Navarro I.T. 2017. Seroepidemiology of toxoplasmosis in humans and dogs from a small municipality in Parana, Brazil. Ciência Animal Brasileira. 18(e-42102): 1-9.

2 Brun-Buisson C., Legrand P., Philippon A., Montravers F., Ansquer M. \& Duval J. 1987. Transferable enzymatic resistance to third-generation cephalosporins during nosocomial outbreak of multiresistant Klebsiella pneumoniae. Lancet. 330(8554): 302-306.

3 Caliman M.C.W. 2010. Estudo de Vigilância Bacteriológica: Isolamento, Fatores de Virulência e Resistência Antimicrobiana de Cepas de Escherichia coli isoladas de Gatos Domésticos na Região de Ribeirão Preto. 113f. Jaboticabal, SP. Dissertação (Mestrado em Microbiologia Agropecuária) - Programa de Pós-graduação da Faculdade de Ciências Agrárias e Veterinárias, Universidade Estadual Paulista.

4 Carattoli A. 2008. Animal reservoirs for extended spectrum beta-lactamase producers. Clinical Microbiology and Infection. 14(suppl 1): 117-123.

5 Carvalho V.M., Spinola T., Tavolari F., Irino K., Oliveira R.M. \& Ramos M.C.C. 2014. Infecções do trato urinário (ITU) de cães e gatos: etiologia e resistência aos antimicrobianos. Pesquisa Veterinária Brasileira. 34(1): 62-70.

6 Clinical and Laboratory Standards Institute (CLSI). 2013. Performance Standards for Antimicrobial Disk and Dilution Susceptibility: Tests for Bacteria Isolated from Animals. CLSI Documents VET01-S2. Clinical and Laboratory Standards Institute. Wayne: CLSI, 73p.

7 Cooke C.L., Singer R.S., Jang S.S. \& Hirsh D.C. 2002. Enrofloxacin resistence in Escherichia coli isolated from dog with urinary tracts infections. Journal American Veterinary Association. 220(2): 190-192.

8 Fernandes M.F., Moura Q., Sartori L., Silva K.C., Cunha M.P.V., Esposito F., Lopes R., Otutumi L.K., Gonçalves D.D., Dropa M., Bueno M.F.C., Garcia D.O., Knöbl T., Moreno A.M. \& Lincopan N. 2016. Silent dissemination of colistin-resistant Escherichia coli in South America could contribute to the global spread of the mcr-1 gene. Eurosurveillance. 21(17): 1-6. 
9 Guardabassi L., Schwarz S. \& Lloyd D.H. 2004. Pet animals as reservoirs of antimicrobial-resistant bacteria. Journal of Antimicrobial Chemotherapy. 54(2): 321-332.

10 Jong A., Stephan B. \& Silley P. 2011. Fluoroquinolone resistance of Escherichia coli and Salmonella from healthy livestock and poultry in the EU. Journal of Applied Microbiology. 112(2): 239-245.

11 Ishii J.B., Freitas J.C. \& Arias M.V.B. 2011. Resistência de bactérias isoladas de cães e gatos no hospital veterinário da Universidade Estadual de Londrina (2008-2009). Pesquisa Veterinária Brasileira. 31(6): 533-537.

12 Krumperman P.H. 1983. Multiple antibiotic resistance indexing of Escherichia coli to identify hihg-risk sources of fecal contamination of foods. Applied Enviromental Microbiology. 46(1): 165-170.

13 Lago A., Fuentefria S.R. \& Fuentefria D.B. 2010. Enterobactérias produtoras de ESBL em Passo Fundo Estado do Rio Grande do Sul, Brasil. Revista da Sociedade Brasileira de Medicina Tropical. 43(4): 430-434.

14 Manian F.A. 2003. Asymptomatic nasal carriage of mupirocin-resistant, methicillinresistant Staphylococcus aureus (MRSA) in a pet dog associated with MRSA infection in household contacts. Clinical Infectious Diseases. 36(2): 2628.

15 Minarini L.A.R., Gales A.C., Palazzo I.C.V. \& Darini A.L.C. 2007. Prevalence of community: occurring extended spectrum beta lactamase producing Enterobacteriaceae in Brazil. Current Microbiology. 54(5): 335-341.

16 Oliveira P.A., Moura R.A., Rodrigues G.R., Lopes K.F.C., Zaniolo M.M., Rubio K.A.J., Dias E.H., Oliveira L.A., Chiderolli R.T. \& Gonçalves D.D. 2016. Detection of extended spectrum beta-lactamases and resistance inmembers of the Enterobacteriaceae family isolated from healthy sheep and dogs in Umuarama, Paraná, Brazil. Semina: Ciências Agrárias. 37(2): 829-840.

17 Papenfort K. \& Blasser B.L. 2016. Quorum sensing signal-response systems in Gram negative bacteria. Nature Reviews Microbiology. 14(9): 576-588.

18 Paula-Dreer M.K., Gonçalves D.D., Caetano I.C.S., Gerônimo E., Menegas P.H., Bergo D., Lopes-Mori F.M.R., Benitez A., Freitas J.C., Evers F., Navarro I.T. \& Martins L.A. 2013. Toxoplasmosis, leptospirosis and brucellosis in stray dogs housed at the shelter in Umuarama municipality, Paraná, Brazil. Journal of Venomous Animals and Toxins Including Tropical Diseases. 19(23): 1-5.

19 Peirano G., Asensi M.D., Pitondo-Silva A. \& Pitout J.D. 2011. Molecular characteristics of extended-spectrum $\beta$-lactamase-producing Escherichia coli from Rio de Janeiro, Brazil. Clinical Microbiology and Infection. 17(7): 10391043.

20 Prescott J.F., Hanna W.J.B., Reid-Smith R. \& Drost K. 2002. Antimicrobial drug use and resistance in dogs. Canadian Veterinary Journal. 43(2): 107-116.

21 Possamai M.F. 2017. Atividade bactericida in vitro dos óleos essenciais de orégano (Origanum vulgare), capim-limão (Cymbopogon citratus) e erva-cidreira brasileira (Lippia alba) frente a isolados bacterianos oriundos de rações de gatos. 61f. Umuarama, PR. Dissertação (Mestrado em Ciência Animal), - Programa de Pós-graduação em Ciência Animal da Universidade Paranaense.

22 Quinn P.J., Carter M.E., Markey B. \& Carter G.R. 1994. Enterobacteriaceae. In: Clinical Veterinary Microbiology. London: Wolfe Publishing, pp.209-236.

23 Quinn P.J., Markey B., Carter M.E., Donnell W.J. \& Leonard F.C. 2005. Microbiologia veterinária e doenças infecciosas. Porto Alegre: Artmed, pp.115-130.

24 Rodrigues P.C. 2002. Bioestatística. 3.ed. Niterói: EdUFF, pp.223-238.

25 Souza R.B., Magnani M. \& Oliveira T.C.R.M. 2010. Mecanismos de resistência as quinolonas em Salmonellla spp. Semina: Ciências Agrárias. 31(2): 413-428.

26 Teo J., Cai Y., Tang S., Lee W., Tan T.Y., Tan T.T. \& Kwa A.L. 2012. Risk factors, molecular epidemiology and outcomes of ertapenem resistant, carbapenem-susceptible Enterobacteriaceae: a case-case-control study. Critical Care. 7(3): 1-8.

27 Wanderley M.C.P. 2015. Ocorrência de Escherichia coli resistente a antimicrobianos em diferentes sítios corporais em uma população diversa de gatos saudáveis. 118f. Jaboticabal, SP. Tese (Doutorado em Microbiologia Aplicada) Programa de Pós-graduação da Faculdade de Ciências Agrárias e Veterinárias, Universidade Estadual Paulista.

28 World Health Organization for Animal Health (WHO). 2014. Antimicrobial resistance. Global Report on Surveillance. WHO Library. Geneva: World Health Organization, 265p. 